\title{
Literary Projection of Nature and Environment in Abhijñāna-Śakuntalam: Reflection of Faith-Based Care for the Environment
}

\author{
Bipin Kumar Jhaa ${ }^{1}$, Abhishek Tripathi ${ }^{2 *}$ \\ ${ }^{1,2}$ Nalanda University, Rajgir, Bihar, India \\ *<atripathi.sbs18@nalandauniv.edu.in>
}

\begin{abstract}
Abhijñāna Śākuntalam, as Sanskrit play by the renowned poet Kālidāsa offers the utmost importance to nature and the environment. It is the responsibility of all and everyone, irrespective of their social strata; king, sages, their sons and daughter and their disciples' given equal responsibility and accountability to care for the environment. The king is advised not to kill the animals roaming inside a guarded territory of the Ásrama (cottage) of the sages. Śakuntala was advised by her father Kanva to look after the plants and animals. The reciprocal nature of mutual dependence between Human and Environment vividly delved in Abhijñāna Śäkuntalam. The King's major responsibility includes preserving environment, one such example; the text eludes King Dusyanta, taming a mad elephant, destroying the plants, while the king introduces himself to the Śakuntala the very first time, another example is, the opening statement in Abhijñāna Śäkuntalam reflects the concern of environment protection, the very importance of the people who care and nurture environment and have describes as: Yāsrsștihsrașturādyā vahatividhihutam yāhaviryā ca hotrī, Ye Dvekālam vidhattah śrūtivișaya guṇa yā sthitā vyāpyaviśvam, Yām āhuḥ sarvabüja-prakrtiriti yayā prānininạ prānavantah, Pratyakșābhih prapannastanubhiravatuvastābhiraștābhirīsah [A.S 1.1]. Eight forms has Shiva, Lord of all and king: And these are water, first created thing; And fire, which speeds the sacrifice begun; those who care for nature; and time's dividers, moon and sun; The all-embracing ether, path of sound; The earth, wherein all seeds of life are found; And air, the breath of life: may he draws near, Revealed in these, and bless those gathered here (Ryder,1999). The eight elements described in Abhijñāna Śăkuntalam viz; the five gross elements along with time and space, and the people in general who care for nature are considered to be the constituents of god or Shiva. The environment and nature treated here as one entity represented here as, Lord Shiva, one of the trinities of Hindu god, shows the reflection offaith in relation to the care for the environment.
\end{abstract}

Keywords: religion, Sanskrit text, environment, faith. 


\section{Introduction}

The World is invariably filled with three types of sufferings (Duhkha), Adhibhautik, Adhidaivik, and Adhyatmika; which are concerned with Nature, God and Body subsequently. Deliverance from these three types of Duhkha is the goal of all beings. Our $\bar{A} c \bar{a} r y a$ sages have shown the path for liberation from all such sufferings. The Indian wisdom and intellectual tradition value a holistic understanding of knowledge. Knowledge where all disciplines are in unison. It is important to note that this knowledge and is mentioned in the upanișad as Avidyā VidyāVidyā or Parā-Aparā Vidyā. Sákkuntalam imbibes the Vedic Philosophy and Aupanișadic values and ethos to describe the environment in a poetic expression in the form of a Sanskrit drama.

There is a total of seven amka (chapters) in the play. Throughout the text in those seven amka, Kālidāsa has brought the environment and conservation of nature as one of the major themes of the text.

\section{Environment and Its Depiction in Śăkuntalam}

\section{A. The beginning}

In the very beginning of the text it says:

Grīṣmasamayamadhikṛtya gīyatām samprati hi-

Subhagasalilāvagāhāh pāțalasamsargasurabhivanavātāh
Pracchāyasulabhanidrā divasāḥ parināmaraman̄ìāh

İṣadīṣa ccumbitāni bhramaraị̣ sukumāra kesaraśikhāni

Avatamsayanti dayamānāh pramadāḥ śirīṣakusumāni.

\section{[A.S 1.3-4]}

Poetic expression presented in the first amka of the play, the song depicts the value of perfection in nature. The beauty of summer inside the Áśrama and the flowers nature has offered to it. A panoramic description of how all of them reside in Aśrama in harmony given special attention to biodiversity through such verses.
Vaikhānasah - (hastamudyamya)
Rājan-äśramamrgoyam na hantavyo na hantavyah Na khalu na khalu bānặ
sannipātyoyamasmin

Mṛduni mrgaśarīre pusparāaśávivāgnih. Kva bata harinakānām jìvitam cāti lolam. Kva ca nisítanipātā vajrasārāạh śarāste. Tatsādhukrtasandhānam pratisaṃharasāyakam

Ārtatrānāya vah śastram na prahartumanāgasi.

[A.S 1.10-11]

King Dușyanta, the protagonist of the play, goes hunting in the Áśrama, King advised not to kill innocent creatures as it is the duty of the king to protect the nation by preservation and conservation of the environment. It shows here that nation, it is not just the protection of material wealth, 
conservation of the natural assets and environment is also a Dharma, towards the nation. Natural diversity is very critical for a nation and hence for King Dușyanta, It is forbidden to kill this deer, it is also a creature and very much part of the natural diversity of the Áśrama.

\section{B. Female protagonist and environment}

Anasūyā-halā śakuntale, tvattopi tatakāśyapasy āśram-avrkșakāh priyatarāh iti tarkayāmi

Yena navamālikā kusumapelavāpi tvameteșāmālavālapūraṇe niyuktā

Śakuntalā -na kevalam tātaniyoga ev asti me sodasnehopyeteșu (iti vṛșasecanam nirupayati)

Rājā-katham iyam sā kanvaduhitā asādhudarśi khalu tatra bhavan kāśy apoyaimāmāśramadharmeniyuñkte

\section{Idạ̣ kilāvyājamanoharaṃvapus}

Tapaḥkṣamam sādhayitum ya icchati

Dhruvam sa nīlotpalapatradhārayā

Śamīlatām cchettumṛși vyavasyat.

$$
\text { [A.S 1.17] }
$$

In the first amka of this play, the father of Śakuntalā i.e. Rṣi Kạ̣va, offers his daughter very fatherly advice, to water the trees of the Áśrama and look after the animal in the Áśrama as must do, daily routine. He shows utmost affection and care for trees and animals and treat them as his own children. Śakuntalā's the testimony makes it clear that the environment treated here as a family. This reflects the importance of the environment on equal footings as children.

Śakuntalā, the female protagonist in the play, her attires and perfection of beauty is immersed in nature. All her embellishments are from nature itself, and even nature covers her body and she is a reflection of owing nature on herself.

\section{Abhijñāna Śākuntalam and society}

This text talks not only about human beings but also animals. The King gives orders to his followers not to disturb animals.

Gāhantāṃmahișānipānasalilaṃśrṛn gairmuhustāditam

Chāyābadhdakadambakaṃmrgakula mromanthamabhyasyatu

Viśrabdhakriyatāṃvarāhatatibhirmu stākșatihpalvale

Viśrāmaṃlabhatāmidamcaśithilajyā bandhamasmadhdanuh

\section{[A.S 2.6]}

The environment depicted here as the way of life, an integral part of the daily life in Sākuntalam. It described as extremely critical for society. There is a mutual relationship between the human and the non-human. If we do not conserve the environment, our existence is endangered. In the second amka of the play, that essential relationship between nature and society. It indicates the reciprocal relationships society and environment complement each other. 
D. Nature and its Boundaries.

The King Dusyanta promises to Anusūyā and Priyamvadā, the friends of Śakuntalā-

Parigrahabahutvepi dve pratișthe kulasya me

Samudrarasanā corvīm sakhī ca yuvayoriyam.

\section{[A.S 3.18]}

Not only in terms of the environment. The tree plant but the beach is included. Protecting the sea in the third issue. It is clearly stated that the king has the ultimate duty.

E. Environmental diversity-symbolism

If we care environment it cares for us, hence we must care it-

Pātum na prathamam vyavasyati jalạ̣ yuṣmāsvapìteșu yā

Nādatte priyamaṇdanāpi bhavatām snehena yā pallavam

Adye vah kusumaprasūtisamaye yasyā bhavatyutsavah

Seyam yāti śakuntalā patigṛam sarvairanujūāyatām

[A.S 4.9]

Kṣaumạ̣ kenacidindu pāḍtaruṇā māñgalyamāviṣkrtam

Nișthyūtaścaraṇopabhogasulabho lākșārasah kenacit

Anyebhyo vanadevatā karatale rāparvabhāgotthitai

Rdattānyābharaṇāni tatkisalayodbhe dapratidvandibhih

[A.S 4.5]
Then the fourth amka, for the environment and society, which we can consider trees and plants as a symbol of biodiversity. There has been talk of conversation with nature and its constituents with humans. At the time of Śakuntalā's brides' farewell, flora and fauna and animals look like their relatives, trees and plants are bringing adornment to them. It is important to note that these are the times when nature was protected, that is, when we preserved our nature as our day to day responsibility, only then nature reciprocate and protect and enrich our quality of life. The preservation and conservation of nature are done by one generation, look after by one, benefits to later generations, the water offered to plant eventually is for everyone, and the plants planted and nurtured much before of, they reap fruits or other benefits to us.

\section{F. Nature and Social arrangements}

Śakuntalā asks his father when she would revisit his native home? His father gives a very significant answer.

Bhūtvācirāya caturanta mahīsapatn̄̄

Dausyantimapratiratham tanayamniveśya

Bhartātadarpitakuțumbabhareṇasā rdham

Śāntekarișyasipadampunarāśrame’ smin

[A.S 4.20]

In the fourth amka, the key to social system sustainability is 
discussed. Environment protection, social protection, family responsibility, protection of the nation. All of this is especially seen here following ethical rules. Duty of child towards father, duty of father towards child, duty towards citizens, and duty of environment towards citizens are all widely discussed.

G. King, kingdom and water conservation

Bhavanti namrāstaravah phalägamaih

Navāmbubhirdūravilambinoghanāh

Anudhdatāh satpurușāh samrdhdibhih

Svabhāvaevaișa paropakāriṇām

\section{[A.S 5.12]}

The fifth amka widely deals with morality. This verse of the play narrates to be humble and polite even you are in prosper situation. We may learn how to be polite from nature. Trees bow down when fruits come; the cloud bows down when it is prosperous with water. Like this, if you are a good-mannered human you must be polite. The disciples of sage also talk about the water reservoir. Nowadays we protect water pond because we need it but those students say to save water because it is also part of nature. It also needs the coexistence.

$H$. Water bodies, diversity and cyclical interdependence

Puruṣah-aham jālonigālādibhir matsyabandhanop
Ayaih kuṭmbabharanaṃaromi.

Śyālah- (vihasya)

viśudhdaidānīmājīvah

Puruṣah-bhartah, māevambhaṇa

Sahajam kila yad vininditam na khalu tatkarma vivarjanīyam

Paśumāraṇa karmadārunonukampā mrdureva śrotriyah.

Śyālah-tatastatah purușahkasmin divasekhandaśo rohitamatsyomayākalpitah...

\section{[A.S 6.1]}

The sixth amka narrates about the diversity of water bodies. The pond is dedicated to nature.

\section{Harmony and Nature}

Mākhalu cāpalaṃkuru kathaṃgata evātmanahprakrtim? Rājā(karnamdatvā)abhūmiriyama vinayasyako nu khalveșanișidhyate? (śabdānusāreñāvalokya, savismayam) aye ko nu khalvayam anubadhyamānastapasvinībhy $\bar{a}$ mabālasattvobālah ? ardhapìta stanam māturamardakliștakesaram prakiḍitum siṃhaśiśum balātkārenakarșati

\section{[A.S 7.14]}

Finally, in the seventh amka, there has been talk of mutual harmony between these two animals and social animals. A boy Bharata. Description Is playing with What else could be a better example than this? Maharishi The description of the Āśrama of Mārici is very well known. In this way, we can say. 


\section{Conclusion}

The care for the environment considered religious dharma, those persons who inclined towards taking responsibility and accountability of nurturing the environment, considers a godly figure. The reciprocal sum game between nature and humans for environment conservation based on long term commitments and planning, like Naturopathy medicines are normally consumed to remain fit and healthy, not when one has fallen sick, they are designed as a preventive measure for the continuation of a healthy life. In the play, rituals like brides farewell not completed until Śakuntalā visited the pond in the Áśrama before finally left with Dusyanta to his Kingdom. Nature treated as auspicious, just before a married couple begins their married life.

In this way, we can say that Sāauntalam delves into the diversity of nature, deliberates upon various dimensions in the context of environmental protection and care. Forest protection, flora and fauna conservation, reservoir conservation, water conservation. The sense of harmony amongst human and wild animals, especially the reciprocal relationship between the king and the citizens including animals, plants, trees under his kingdom, presents a narrative and Philosophical conjecture that even those who conserve nature are treated no less than constituents of God. Śākuntalam offers a natural and mutual harmony amongst human and nonhuman alike. It motivates us towards the conservation and protection of nature. Modern age problems, flood or drought and recent bush fire in Australia, due to our negligence and breaking of the harmony between nature and humans. Polluted air leads us to health issues, mainly among children, and is alarming and turning into a global emergency. Humans and the environment lived together in unison since human evolution took place in Africa and spread to another part of the world, diversity and environmental harmony are the answer to our environmental concerns. Abhijñāna Śākuntalam attributes to the people of that time, and the social system and governance of that period.[]

\section{Bibliography}

D Bhattacharya, J. N., and NilanjanaSarkar. 2004, A History of Sanskrit Literature Gardners Books.

E.H.Johnston, The Buddhacarita, Acts of the Buddha, 1972

Kale M. R-Abhijñānaśākuntalam of Kālidāsa-Motilal Banarsidass publishers private limited, Delhi.

Kale. M.R. 1967 Malatimadhava of Bhavabhuti, MLBD.Delhi. 
Krishnamacariar, M. (1974) History of Classical Sanskrit Literature, Motilal Banarsidass Publishers, Delhi.

Krishnamoorthy. K- Kālidāsa-Sahitya Akademi, NewDelhi.

Macdonell, A.A. (1971) A History of Sanskrit Literature, Motilal Banarsidass,

MacDonell, Arthur (2004). A History of Sanskrit Literature (in Norwegian). Kessinger Publishing ISBN 978-1-4179-0619-2.

Mainkar, T.G. (1971) Studies in Sanskrit Dramatic Criticism, Motilal Banarsidass Delhi,

Mirashi, V.V. (1974) Bhavabhūti, His Date, Life and Works, Motilal Banarsidass Publishers, Varanasi, 1st edn.

Morgan, Les (2011). Croaking frogs: a guide to Sanskrit metrics and figures of speech. Los Angeles: Mahodara Press. p. 1.

Narang S.P-Juridical studies in Kālidasa-Rashtriya Sanskrit Sansthan,New Delhi.

Ranganath .S.(2009) Modern Sanskrit in Karnataka, New Delhi, Rashtriya Sanskrit Sansthan P.7.ISBN 978-81-86111-21-5.

Sharma, Yogeshwaradatta. Kāvyādarśa, with Hṛdayaṅgamā-Prabhā-Vivṛttițīkā commentary. New Delhi: Nag Publishers, 1999.

Shastri, Satyavrat. Bhavitavyānāṃ Dvārāṇi Bhavanti Sarvatra. Ātmakathā. Delhi: Vijaya Books, 2015.Shrivastava, A. L. History of India. Agra: Shiva Lal Agrawal \& Co. Educational Publishers, 1998. 